\title{
The OECD Financial Transactions Discussion Draft and BEPS Actions 8-10
}

\section{INTRODUCTION}

On 3 July, the OECD released a public discussion draft on financial transactions (the discussion draft), related to BEPS Actions 8-10. ${ }^{1}$ The main purpose of the discussion draft is to determine the arm's length principle applicable to certain financial transactions within a multinational enterprise (MNE) group. Such transactions include intra-group loans; treasury activities, such as cash pooling and hedging; financial guarantees; and captive insurance companies.

The discussion draft implements Actions 8-10 policy on transfer pricing based on functions, assets and risks. In the case of financial transactions, the discussion draft sets forth guidance aimed at determining the actual transaction and its accurate delineation, by identifying its capital structure; the functions carried out by parts of an MNE group in the capital structure and related transactions; the risk (including zero-risk) borne by those parts in the transactions; and criteria helping to quantify intra-group financial transactions. ${ }^{2}$

\section{THE CONTROVERSIAL ROLE OF TRANSFER PRICING RULES IN INTRA-GROUP FINANCIAL TRANSACTIONS}

The release of the financial transactions discussion draft is the outcome of a consensus reached at the OECD. The core controversial issue concerns the adequacy of transfer pricing rules and the arm's length principle based on functions, assets and risks, for purposes of intra-group financial transactions. ${ }^{3}$ This is so because the capital structure of a borrowing entity that is part of an MNE group differs from that which would exist in the case of independent entities.
In fact, one can argue that it is very difficult - if not impossible - for tax administrations to decide on the adequate capital structure of an MNE group, and to adjust financial transactions in light of the arm's length principle, except in extreme cases. Such extreme cases might be seen, for example, where a related company advances funds denominated as a loan (capital funding), if it were clear that, 'in light of all good-faith financial projections' of the borrowing company for a certain number of years, that company would be unable to service a loan of such amount. ${ }^{4}$ In other words, in the described case, an MNE of the group would not be able to borrow capital on its own.

These extreme cases of intra-group financial transactions are the ones addressed in the discussion draft, ${ }^{5}$ and one can deduce that a reason for the OECD consensus in approving the discussion draft, lies in the fact that the draft applies transfer pricing rules to extreme cases in which arm's length reasoning will probably work.

Moreover, as is recognized in the discussion draft, MNE groups very often centralize treasury functions aimed at making the financing of the commercial business of the group as efficient as possible, and implement risk mitigation strategies, including with regard to transferring risk within the group, aiming to mitigate exposure to foreign exchange and commodity prices. ${ }^{6}$ Treasury strategies used by MNE groups include cash pooling, hedging and group financial guarantees. $^{7}$ By contrast, none of these are used by, or accessible to, individual independent companies.

Thus, pricing and allocation of revenue related to the aforementioned treasury strategies, in accordance with transfer pricing rules, may also be difficult. For example in the cash-pooling analysis discussed in section C. 2 of the discussion draft, a functional analysis is recommended, focused on the group synergies created through deliberate

\section{Notes}

OECD, Discussion Draft, BEPS Actions 8-10: Financial Transactions, OECD/G20 Base Erosion and Profit Shifting Project (OECD Publishing 3 July 2018).

Ibid., e.g. B and C.1.

Criticizing transfer pricing rules as inadequate for the current international system, see Y. Brauner, Transfer Pricing in BEPS: First Round - Business Interests Win (But, Not in Knock-Out), 43(1) Intertax 72 (2015).

OECD, supra n. 1, e.g. para. 17.

Ibid., e.g. para. 17.

Ibid., e.g. paras 38-43.

Ibid., e.g. C and D. 
concerted action, and the pricing methodology goes in the direction of a profit split. ${ }^{8}$

Interest paid is not assessed on a transaction-by-transaction basis, as transfer pricing rules typically recommend, but through sharing the results among the cash pool members, and then remunerating the cash pool leader for the functions performed:

An advantage of a cash pooling arrangement may be the reduction of interest paid or the increase of interest received, which results from netting credit and debit balances. The amount of that group synergy benefit calculated by reference to the results that the cash pool members would have obtained had they dealt solely with independent enterprises, would generally be shared by the cash pool members, provided that an appropriate reward is allocated to the cash pool leader for the functions it provides.

\section{Characterization of the instrument}

A multi-factor analysis, aimed at characterizing the instrument, is accepted by the discussion draft. ${ }^{10}$ The discussion draft stresses that the first purpose (of section 1) is to determine whether a purported loan should be regarded as such for tax purposes, or whether it is some other kind of payment. ${ }^{11}$ Thus, classification of the actual transaction precedes pricing, although both will involve a 'thorough identification of the economically relevant characteristics of the transaction', such as examination of the contractual terms of the transaction, a functions/assets/risk analysis, the characteristics of the financial products or services, the economic circumstances of the parties and of the market, and the business strategy of the group, ${ }^{12}$ in line with the Actions 8-10 Final Reports. ${ }^{13}$

Several problems can arise as a result of this methodology. Problems can range from differing income classification by the involved jurisdictions, to attribution of different risk rates of return to the different MNEs operating in different jurisdictions, yet belonging to the same group. First, contracting states might not agree on the classification of the income. For example an outcome of varying classifications could be a hybrid instrument. Assuming that the source jurisdiction (Country A) of an MNE (Company X) engaged in the development of an intangible, classifies the amount paid as interest, the amount of deductible interest in the source state can be assessed in light of Article 9 of the OECD Model Tax Convention, ${ }^{14}$ and an interest deduction limitation rule may also be applied. In turn, if the residence state (Country B) of the beneficial owner of the income (Company $\mathrm{Y}$ of the same group) classifies it as a dividend (which, as a rule, would be exempt) and applies a defensive response, it would not acknowledge adjustments to the amount of interest in light of Article 9 of the OECD Model and there would be juridical double taxation.

Moreover, readjustment of the risk-rate of return may also lead to juridical double taxation if a third Company, $Z$, of the same group, comes into play. Assume that Country $C$ applies a functional analysis to Company $\mathrm{Z}$ (through analysis and evaluation of the risks inherent in the loan; the capability to commit capital of the business to the investment; whether it determines the terms of the loan; organization and documentation related to the loan (all in paragraph 24 of the discussion draft)), and concludes that risks have been borne by Company $\mathrm{Z}$, and not by $\mathrm{Y}$ in Country B. Country $\mathrm{C}$ will classify the income as interest, readjust the risk-rate of return and allocate a 'premium' to Company Z, contributing to an increase juridical double taxation. ${ }^{15}$

Where more than two jurisdictions are involved, Article 25 of the OECD Model will play a role in cases similar to the described hypothetical cases, as acknowledged by the discussion draft:

This could arise, for instance, where a funded party is entitled to deduct interest expense up to an arm's length amount, but the funder is entitled to no more than a riskfree rate of return ..., and the residual interest would be allocable to a different related party exercising control over the risk. ${ }^{16}$

If two or more involved contracting states agree upon the classification of the income - as interest, for example - Article 9 of the OECD Model (and Article 25 of the OECD Model, if necessary) will be applicable, and thin capitalization or

\section{Notes}

8 Ibid., e.g. para. 103. See also V. Chand, Transfer Pricing Aspects of Cash Pooling Arrangements in Light of the BEPS Action Plan, 23(1) Int'l Transfer Pricing J. 38-47 (Jan./Feb. 2016).

OECD, supra n. 1, para. 107

10 Ibid., e.g. para. 8.

11 Ibid., e.g. para. 10.

12 Ibid., e.g. paras 15 and 16-36.

13 OECD, Aligning Transfer Pricing Outcomes with Value Creation - Actions 8-10 Final Reports, OECD/G20 Base Erosion and Profit Shifting Project (OECD Publishing 5 Oct. 2015), para. 1.36

14 And any adjustment provisions have to be authorized by the domestic law of the State. See V. Chand, Transfer Pricing Aspects of Intra-Group Loans in Light of the Base Erosion and Profit Shifting Action Plan, 44(12) Intertax 885 (et seq.) (2016). On the role of Art. 9 of the OECD Model, see also J. Wittendorff, The Transactional Ghost of Article 9(1) of the OECD Model, 63(3) Bull. Int'l Tax'n 110-114 (2009).

15 This would be a result of the procedure described. OECD, supra n. 1, e.g. in paras 12-17.

16 OECD, supra n. 1, Box B.6., Question to commentators. 
interest barrier rules may work as fall back domestic rules. This will be so if the contracting states use transfer pricing rules to adjust the arm's length conditions of financial transactions, as well as if they accept the MNE group's application of the transfer pricing rules to the financial transactions.

\section{The aDEQUACY OF tRANSFER PRICING RULES TO CHALLENGE THE CAPITAL STRUCTURE OF AN MNE GROUP}

Assuming that the discussion draft applies to extreme cases where tax administrations are capable of challenging the capital structure of an MNE group, the discussion draft aims to achieve an 'accurate delineation of the actual transaction' to 'determine the amount of debt to be priced'. ${ }^{17}$

In respect of financial transactions, transfer pricing assessment arguably requires an analysis of various elements affecting the performance of businesses in the industry sector in which the group operates. This implies an analysis of different factors, mentioned in the discussion draft: the particular point of an industry in its life cycle; the effect of government regulations; the availability of financial resources in a given industry in its life cycle; how the group prioritizes the funding needs among different projects; the strategic significance of a particular MNE within the group; whether the MNE is targeting a specific credit rating or debt-equity ratio; and whether the MNE is adopting a funding strategy different to the predominant one in the sector. $^{18}$

Having this in mind, some OECD countries hold that transfer pricing rules are not adequate to assess the capital structure of MNEs, and give, in practice, priority to rules limiting the deduction of interest when MNE and national groups are at stake. Such countries may use, for example, thin capitalization rules, or interest barrier deduction rules (EBIDTA), including safe harbours (the possibility to carry deductibility forward and/or back; the possibility to apply the interest barrier to one MNE of the group or to take into account the group's average debt).

However, transfer pricing rules are applicable to pricing, even when there is difficulty in assessing the capital structure. In fact, there seems to be no controversy in applying the comparable uncontrolled price method to financial transactions. This is due to the widespread existence of markets for borrowing and lending, and the frequency of such transactions between independent borrowers and lenders. ${ }^{19}$ Competition between lenders; the availability of pricing information given the characteristics of the loan; and the credit rating of the borrower, will all tend to narrow the range of interest rates. ${ }^{20}$

All in all, the parts of the discussion draft on the criteria applicable to pricing the transactions, seem to be consensual among OECD countries.

\section{Transfer PRICING RULES IN INTRA-GROUP FINANCIAL TRANSACTIONS AND THE PRINCIPAL PURPOSE TEST}

Inadequacy of transfer pricing rules to assess the capital structure of MNEs, results from the lack of comparable transactions, and therefore the 'market price' and the 'normal conditions' underlying a transaction are hardly applicable to intra-group financial transactions. When applying transfer pricing rules to intra-group financial transactions, the discussion draft stresses the importance of identifying the economically relevant characteristics of the transaction - commercial considerations and the business strategy. ${ }^{21}$ Furthermore, following the Actions 8-10 Final Reports, ${ }^{22}$ paragraph 7 of the discussion draft suggests a comparison test, between the arrangements adopted in the intra-group transaction (or in relation to it) and those that would have been adopted by independent enterprises behaving in a commercially rational manner:

Where it is considered that the arrangements made in relation to the transaction, viewed in their totality, differ from those which would have been adopted by independent enterprises behaving in a commercially rational manner in comparable circumstances, the guidance at Section D. 2 of Chapter I may also be relevant. ${ }^{23}$

This comparison test operates similarly to a general antiavoidance rule (GAAR) if it leads to reclassification of the income. ${ }^{24}$ Step transactions are to be viewed in their totality, and rational commercial behaviour in comparable circumstances is a standard for ascertaining compliance with transfer pricing rules. Rational commercial behaviour can operate under a (the) principal purpose test of the Multilateral Convention to Implement Tax Treaty Related Measures to Prevent Base Erosion and Profit Shifting (the Multilateral

\section{Notes}

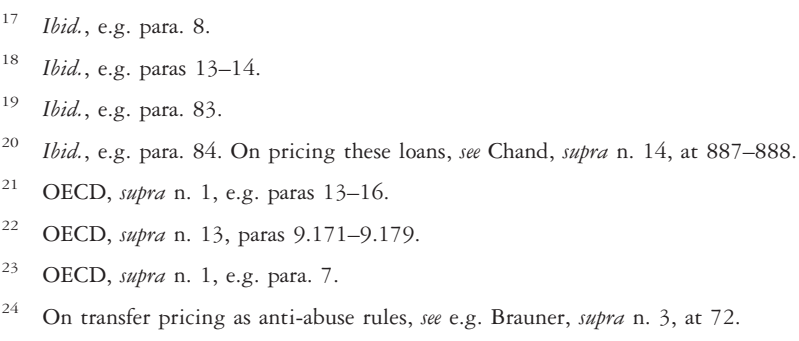


Convention). ${ }^{25}$ Rational commercial behaviour is assessed after determination of the actual transaction, and involves an analysis of, for example, how the group prioritizes the funding needs among different projects; the strategic significance of a particular MNE within the MNE group; and whether the MNE is targeting a particular credit rating or debt-to-equity ratio. ${ }^{26}$

According to Chand, ascertaining whether there is rational commercial behaviour implies a test of whether the borrowing entity 'would ... actually borrow a similar amount at arm's length given the performance of its business' (emphasis added). Furthermore, still according to Chand:

[s]pecifically, the analysis focuses on under what conditions a borrower would have borrowed at arm's length taking into consideration (including but not limited to) features such as (1) its financial situation, (2) the amount of debt and whether taking that amount leaves room to absorb cyclical or seasonal variations, unforeseen events or a fluctuation in interest rates or profits, (3) its costs of borrowing, (4) its debt servicing ability and the possibility to have sufficient cash to operate as a profitable organization and (5) whether the borrower would have taken the loan at all. ${ }^{27}$

Having regard to all relevant facts and circumstances, if there is no rational commercial behaviour, obtaining benefits under a tax treaty (transfer pricing rules as interpreted by the MNE group under Article 9 (deduction in the source jurisdiction and low taxation in the funding jurisdiction)) may be held to be one of the principal purposes of any arrangement or transaction that resulted directly or indirectly in that benefit.

By applying the commercially rational behaviour test, and due to its legal vagueness, tax authorities will be granted broad interpretation powers, also to argue that the interpretation of Article 9 of the OECD Model by the MNE group and the corresponding benefits, are not in accordance with the object and purpose of Article 9 (see the wording of the principal purpose test in the Multilateral Convention). ${ }^{28}$

No doubt, the interpretation of the commercially rational behaviour test by the tax authorities needs to be controlled by tax courts. In rule-of-law jurisdictions, independent tax courts are expected to develop consistent case law that will determine the meaning of this vague concept. However, it is expected that the financial transactions discussion draft will contribute to increasing litigation.

This results from the previous paragraphs of this editorial that in light of the principal purpose test, and in the absence of rational commercial behaviour, the transaction would be ignored and reclassified. If, in light of the transfer pricing rules, as recommended in the discussion draft, the income is reclassified, the procedure and outcome are very similar to those resulting from the principal purpose test. If only the pricing is readjusted, the outcome is different from that resulting from the application of the principal purpose test.

This convergence of the transfer pricing rules applicable to financial transactions and the method adopted by GAARs, and the principal purpose test, is consistent in that it illustrates the holistic approach of the BEPS project. It shows, however, that transfer pricing rules applicable to intra-group financial transactions are a fragile method when seeking to achieve a fair allocation of taxing rights and achieving single taxation.

Ana Paula Dourado General Editor

\section{Notes}

25 OECD, Multilateral Convention to Implement Tax Treaty Related Measures to Prevent Base Erosion and Profit Shifting (OECD Nov. 2016), Art. 7.

26 OECD, supra n. 1, e.g. para. 14.

27 Chand, supra n. 14 , at 889 .

28 Art. 7 - Prevention of Treaty Abuse '1. Notwithstanding any provisions of a Covered Tax Agreement, a benefit under the Covered Tax Agreement shall not be granted in respect of an item of income or capital if it is reasonable to conclude, 9 having regard to all relevant facts and circumstances, that obtaining that benefit was one of the principal purposes of any arrangement or transaction that resulted directly or indirectly in that benefit, unless it is established that granting that benefit in these circumstances would be in accordance with the object and purpose of the relevant provisions of the Covered Tax Agreement'. 